\title{
Synergies and Frictions between Mega-events and Local Urban Heritage
}

\author{
Zachary Jones \\ Department of Architecture and Urban Studies, Politecnico di Milano, Milan, Italy \\ Email: zachary.jones@polimi.it
}

\begin{abstract}
Increasingly, cities have turned to mega-events as part of strategies to secure much desired global recognition and attract future economic investment. These events have a broad range of physical effects on the city and can also introduce new concepts of the city. For historic cities, mega-events can potentially have a profound influence on the city's urban heritage, both physically and how heritage comes to be understood and defined. Recent changing trends in mega-events could come to see them more closely integrated into the existing city fabric, making the potential impact of mega-events on built heritage more pronounced. One long-standing event embedded within the city fabric that serves as a noteworthy example is the European Capital of Culture (ECoC), operating for 30 years and travelling between more than 50 cities. The paper presents the European Capital of Cultures of Genoa 2004, Liverpool 2008 and Istanbul 2010 as three diverse cases with differing themes and roles for heritage in order to review the potential synergy or friction between events and heritage and calls for heritage actors to become more involved in these processes.
\end{abstract}

KEYWORDS urban heritage, heritage management, mega-events, European Capital of Culture, comparative casestudy, Genoa, Liverpool, Istanbul

Received May 5, 2017; accepted November 10, 2017.

\section{The Intersection of Mega-events and Urban Heritage}

For the last 150 years, mega-events have been used as powerful tools to define cities and distinguish them from one another. As cities have sought to compete not just nationally, but globally, the hosting of a mega-event has become a sort of qualifier or standard to be achieved. Ongoing discussions debate the professed benefits they bring to host cities and the reality of their legacy. The legacy of the event deals not just with a physical memory, but also a new image or brand for a city that has been projected through the event. While the literature has often highlighted the use of mega-events in the creation of new icons, sporting venues or infrastructural expansions, the implications of mega-events on the existing urban fabric, particularly areas of urban heritage have been largely undiscussed. In recent years, most mega-events have tended to be constructed as separate sites located near, but not within cities themselves. This paper argues that this trend may shift in the near future and, as a result, will be necessary for city officials, conservationists and academics to anticipate and plan for the potential synergies and frictions between mega-events and urban heritage. The paper will first review the recent changing trends of mega-events set within a broader presentation of the existing literature and a specific focus on the European Capital of Culture program. Then, three cases will be introduced to display the varying degrees of interaction and impact between mega-events and heritage. Finally, the paper will conclude by summarising the key influencing factors that result in either the synergy or friction between events and heritage and a call for heritage actors to become more involved in these processes.

\section{Mega-events and Their Changing Relationship to Cities}

For the last 150 years, mega-events have been used as instruments to define cities and distinguish them from one another. The first World's Fair, today known as the 
Universal Exposition or Expo, was the Great Exhibition of 1851, hosted in London. The first modern Olympics was staged 40 years later in 1896 in Athens, the birthplace of the Classical games in antiquity (Zimbalist 2015). Particularly over the last several decades, cities have turned to mega-events as part of cultural and creative strategies to secure much desired global recognition and attract future economic investment (Horne and Manzenreiter 2006; Roche 1994, 2002; Short 2008; Young and Wamsley 2005). These events are those that can have a broad range of physical and social effects on the city, including mass infrastructure projects or new facilities (Ponzini and Jones 2015), but can also be the cause of more nuanced institutional changes and understandings of the city as a whole (including of the heritage of a city). This phenomenon also serves as a focusing-event that introduces strict deadlines accompanied by huge expectations, the conditions that can potentially induce actors to put aside differences in order to collaborate (McGillivray and McPherson 2012). The ability to gain mass investments restricted to a set timeframe have made mega-events desirable for cities to host, but also presents the potential for synergy or friction with the urban heritage of a city through potential physical alterations to the city, introduction of mass tourism or ideological reinterpretations of the identity of the city.

However, over the last several years, a number of high profile cities including Boston, Rome and Budapest have cancelled their bids to host the Olympic Games, citing extreme costs and low public support. These decisions have come both from top down decisions made by city officials as well as through popular referendums. To broaden the appeal of the Olympics and promote more sustainable practice, Agenda 2020 established new guidelines. Specifically, recommendation 2.2 aims to promote the re-use of existing infrastructures (Gold and Gold 2016; International Olympic Committee 2014) in order to make the events more sustainable and less expensive. This shift could lead to the Olympics once again becoming more closely integrated into the existing city fabric. The previous bid by Budapest for the 2024 Olympics serves as a good example as the city specifically recognised the use of important historic locations throughout the city to serve as venues for sporting events, integrating the games into the city itself. Such an approach greatly increasing the likelihood of mega-events impacting areas of urban heritage more than has been common in past years. With this changing paradigm of mega-events, the European context can provide beneficial examples of how to properly integrate large events within existing city fabric. Over the last 30 years, lesser known cultural mega-events have played an important role in the development of cities and have become a common strategy for cities to turn to.

One such event is the European Capital of Culture (ECoC), a yearlong cultural program consisting of a series of events typically situated within the city. This event is one of the longest running continuous EU policies and the flagship cultural program for the European Commission. Beginning in 1985, the event has operated for 30 years with over 50 cities throughout Europe holding the muchcoveted title of European Capital of Culture (García and Cox 2013; Palmer/RAE Associates 2004). Typically, the activities of the ECoC are embedded directly within the city itself compared to other large events and could therefore serve as a more sustainable model for other megaevents. The focus of this event has often been to present the existing fabric of the city in a new light or in the best possible way. For example, the 1990 Glasgow ECoC played a significant role in shifting perceptions about the city of Glasgow, seemingly transforming it from a down and out post-industrial city to a new cultural destination (García 2005). Though the actual realities of those transformations have been questioned (Mooney 2004; Robertson 1996), the change in understanding of the city affected the long-term decisions made regarding the future direction of the city (Gómez 1998; Németh 2015). Therefore, while in some respects the ECoC may not be considered as large in terms of size or funding as an Olympics or Expo, the ECoC has been used in similar ways leading to significant impacts for many European cities. In fact, cities like Liverpool, over the course of a year of celebrations, attracted four times more visitors than the two week London Olympics at a fraction of the cost.

While the ECoC program may not be as renown as other mega-events, its popularity has inspired a number of similar programs. There has been a UK City of Culture program since 2013 with many British cities desiring to participate following the success of the 2008 Liverpool ECoC. Since 1996 there has also been an Arab Capital of Culture initiative organised through the Arab League and since 2015 there has also been the Italian Culture of Culture in Italy. With the ECoC program slated to continue until 2033, it is a mega-event worthy of continued study. Due to the content of the program and its direct relationship to the city itself, the $\mathrm{ECoC}$ is a relevant mega-event for which to examine how a mega-event can be capable of valuing the city itself, particularly its urban heritage 
(Graham 2002). While large sporting events may differ in many ways from cultural events in terms of their focus, cities often approach and manage mega-events in similar ways (Basso 2017). Therefore, as the Agenda 2020 recommendations become more implemented for the Olympics and mega-events are more integrated into the city itself, it will be important for cities to recognise and plan how to utilise these events for their greatest benefit. The cases presented herein provide three examples of the various ways mega-events can impact the urban heritage of a city, either for its benefit or to put it at risk.

\section{Defining Urban Heritage in the Contemporary City}

Urban heritage refers to one aspect of the larger preservation movement that has developed over the last two centuries, encompassing both tangible and intangible heritage. The defining attributes of what qualifies a place or thing as heritage are not always clearly recognisable (Garden 2006) and ultimately determined by a particular set of values (Mason \& Avrami, 2002). Heritage has been classified in different categories such as cultural, natural, tangible, intangible, built, urban or world heritage. Harvey (2008) likewise recognises the role of contemporary society in defining heritage, but sees it as 'the process by which people use the past' in order to create a contemporary social identity (Ashworth, Graham, and Tunbridge 2007). The evolving ideas and approaches to urban heritage result from shifts in society and economics, globalisation, de-industrialisation, world war, the rise of the experience economy and changing philosophical concepts of the $20^{\text {th }}$ century (Harrison 2013). Heritage is therefore a continually evolving concept that has drastically changed over time, not just in terms of what ultimately becomes recognised as heritage, but as well the basic held beliefs informing those decisions (Lowenthal 1985). UNESCO (2017) defines tangible heritage as that which: '...includes buildings and historic places, monuments, artefacts, etc., which are considered worthy of preservation for the future. The recent Historic Urban Landscape (HUL) approach promoted by UNESCO expands the concept of heritage from a singular structure or city district to a more complex and layered landscape encompassing the whole of the city (Bandarin and Van Oers 2012, Veldpaus et al., 2013). The cases presented in this paper deal with vastly different types of heritage, but have all been recognised at local, national and international levels for their Outstanding Universal Value (OUV) and exist as part of complex urban and cultural landscapes that today face similar issues and threats.
Generally speaking, urban heritage is one of the more particularly sensitive areas of cities, both physically and in terms of its definition and valuing. The introduction of mass tourism, often one of the intended consequences of a mega-event can greatly impact both the physical and the social qualities of these spaces. The decisions made as part of these events can lead also to altering the physical appearance and substance of a place through either conservation or demolition of heritage. These changes can significantly alter or potentially destroy these valued areas of cities. The historic nature of a place can also inversely impact the planning of the event or potentially become a key part of the attraction. While physical changes may be the most immediately visible, the changes to the governance of heritage areas, as well as their definitions, can have the most lasting impact. Whether a city chooses to highlight and promote its built heritage as an integral asset can continue to determine how the city values and protects its heritage even long after the event has ended. The combination of heritage cities and mega-events is therefore one that contains great potential as well as risk and deserves further consideration and study.

\section{The European Capital of Culture: A Mega- event Integrated into the Historic City}

The three selected case studies of Genoa 2004, Liverpool 2008 and Istanbul 2010 represent three very diverse cities in terms of the contents of their events, their planning systems and approaches to heritage. In addition to hosting the ECoC, each city has also been recognised as a UNESCO World Heritage Site (WHS) for being of Outstanding Universal Value. While many of the other ECoC host cities also contain important urban heritage, the quality of being a WHS created another point of comparison between the three cases. The application process for WHS is an intensive process that guarantees these cities have valued their heritage enough to ensure its global recognition. The cases will be used to illustrate the varying ways mega-events impact built heritage through a range of approaches. The selection of cases for this in-depth study is purposely diverse, aiming to better understand how a single event adapts to various contexts in order to find as broad ranging impacts as possible. Specifically, event theme, national planning systems and the role of heritage in the event were the primary factors in determining the host cities to study. These three criteria were chosen as they have the greatest direct relation to the planning and outcomes of the events. While factors such as city size, population or total expenditure of the event will of course 

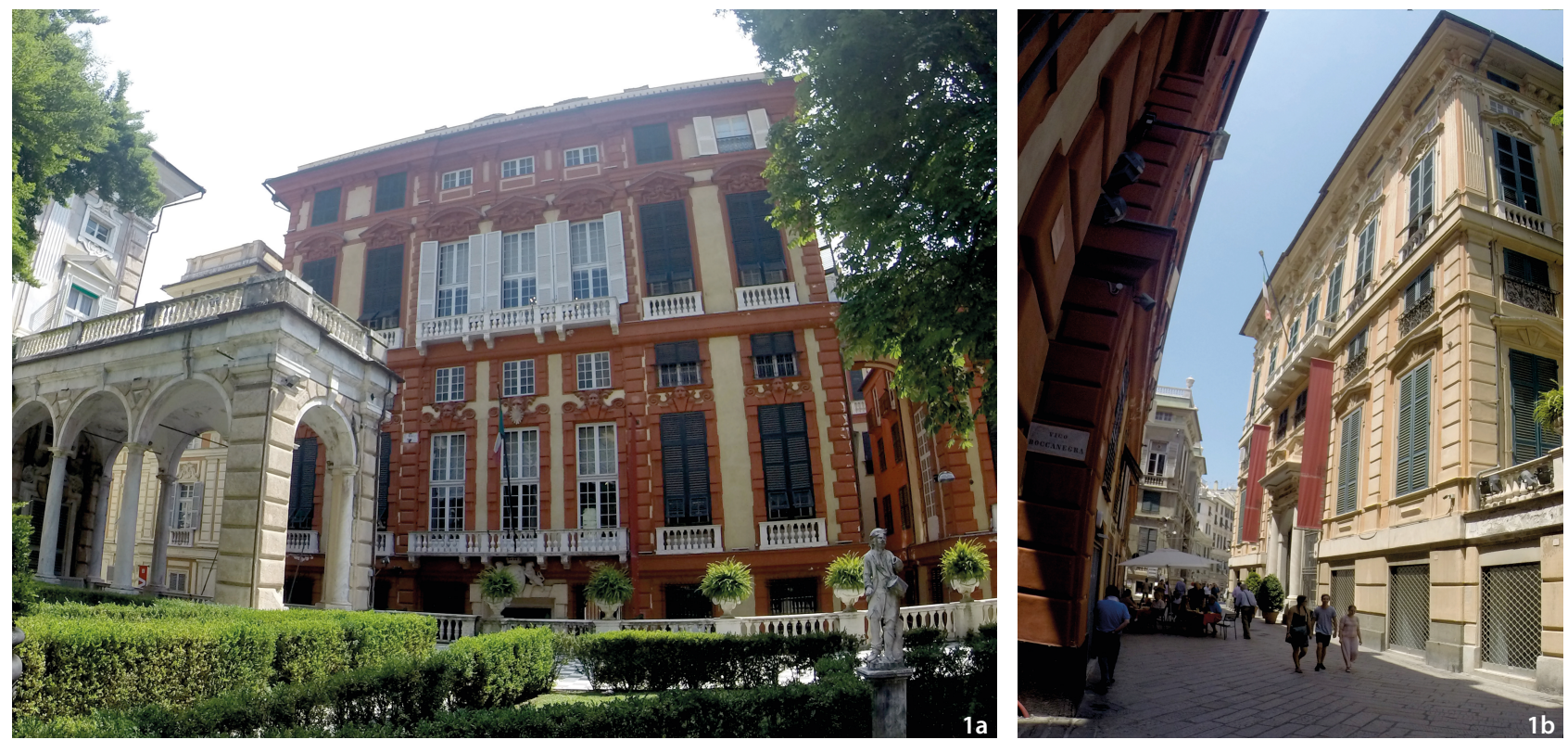

Figure 1a The Rolli Palaces, Palazzo Bianco (Source: the author). Figure $1 \mathrm{~b}$ The Rolli Palaces, Palazzo Rosso (Source: the author).

affect the event in various ways, the selected criteria better represent how and why decisions regarding the event and its heritage were made.

Genoa 2004 is the quintessential example of the use of a mega-event to regenerate the city through a heritageled approach. The WHS site of Genoa was recognised in 2006, two years following the event due to many of the restorations included within as part of a larger longterm strategy of the city that also included another large event, the 2001 G8 Summit. Liverpool 2008 was seen as an ideal counterpoint to Genoa. Though the city received WHS status as 'Liverpool-Maritime Mercantile City' in 2004, the heritage of the city was largely absent from the 2008 events with the site eventually added to the List of World Heritage in Danger in 2012. It presents an interesting opportunity to examine the long term effects of a city choosing to ignore its heritage within a mega-event and the potential secondary effects on heritage. Finally, Istanbul 2010 was chosen both for its focus on heritage, but also for taking the mega-event strategy and expanding it to the extremes within a global city and a heavily centralised planning system. While the ECoC of both Genoa and Liverpool were integrated into strategic plans, the planning of Istanbul's ECoC was more separate from city planning documents, starting life as a bottom-up bid and included more public participation in the selection of projects.

\section{Genoa European Capital of Culture 2004: A Heritage-led Mega-event}

Genoa used the 2004 ECoC event in combination with a series of additional mega-events, all part of a decade-long renewal of the historic centre and its waterfront. The story of Genoa's revival traces its origins to some early renewal projects in the late 1980s, followed by the Expo 1992 and considered ultimately finalised with the 2001 G8 Summit and 2004 European Capital of Culture (Gastaldi 2016; Bonfantini 2015). Through all of these efforts there has been an intense focus on the historic city centre as part of broader long-term plans for the city to develop a new 'centre' to unify the polycentric city and develop a new tourism sector (Gabrielli 2005). A key aspect of Genoa's approach was embedding the event within the wider plans for the city and its involvement of many actors at various levels. Genoa presents a case where the plans for the city were molded around the event, specifically with the 1999 Strategic Conference and 2000 Operation Plan for the Historic Centre. Through these plans, the city brought together the key institutions and actors such as the Ministry of Culture (MiBACT), port authority, universities and the regional government to establish the goals of these plans to address the issues of tourism, education, development, livability and infrastructure (Comune di Genova 1999).

Despite a complex mix of projects and funding sources, the city used the strategic conference and the subsequent operation plan to succinctly guide the mass physical transformation of the city. The series of $16^{\text {th }}$ and $17^{\text {th }}$ century 

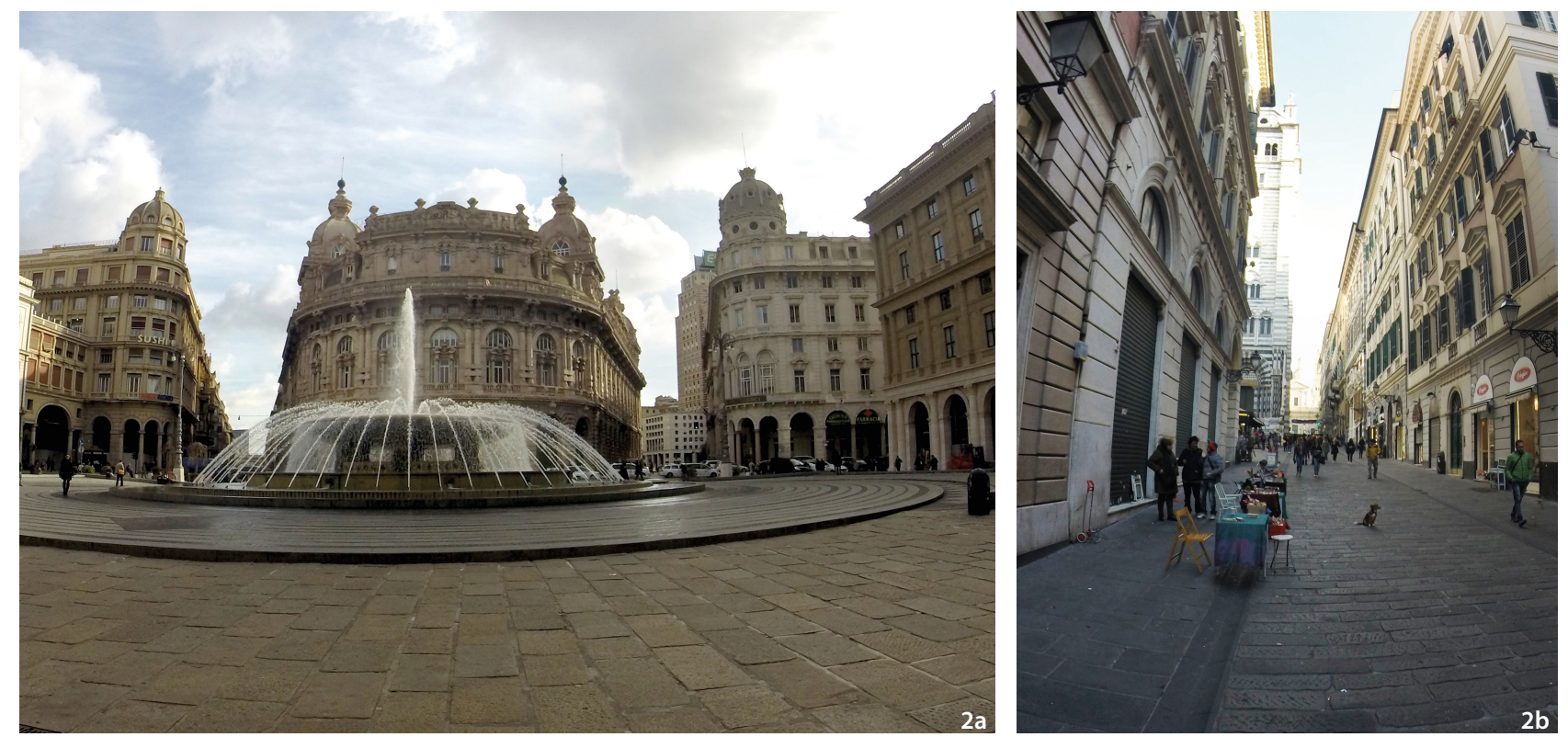

Figure 2a Newly restored and pedestrianised public spaces, Piazza Ferrari (Source: the author).

Figure $\mathbf{2 b}$ Newly restored and pedestrianised public spaces, Via San Lorenzo (Source: the author).

Rolli Palaces were selected to be restored with the explicit intention of applying for UNESCO WHS status, a key part of the city's overall plans (Figure 1a, Figure 1b). The massive shift to focus so heavily on the heritage of the city was a significant change for a city that had not been considered a 'cultural' city during the previous century. These plans and the event reveal a new way of thinking about the city. It was hoped that this investment in heritage would perform multiple tasks for the city. First, it formed the main theme and attraction for 2004. The idea was that the city itself would draw local residents and visitors back to the city centre, both during the ECoC year itself and beyond. Heritage was therefore tasked with creating both a previously non-existent tourism sector as well as an anchor to attract a new creative sector to the city to initiate the regeneration of the city (Comune di Genova 2000). These expectations were quite high, particularly in a place where there was no strong presence of a tourism industry in an already competitive national market for worldrenown heritage offerings including cities such as Rome, Florence and Venice.

Over 160 individual restorations and urban improvement projects were completed between the $2001 \mathrm{G} 8$ Summit and 2004 ECoC, which were conceived of as two phases of a single plan. A key to the proper completion of works was the pre-existing academic studies and research that allowed conservationists to make the best decisions for each individual structure restored (Carbonara 2001). The works completed included renovations of the grandest palaces of the city: Rosso, Bianco, Tursi and Reale, the same first made famous by Reuben. The city also pedestrianised several key streets throughout the city and renovated a number of public spaces (Figure 2a, Figure 2b). These works both improved the urban quality of these spaces to make them more accessible and enjoyable as well as to guarantee the long term protection of the city's heritage by significantly reducing harmful pollution (Figure $3)$. Because of the advanced preparation and integration of the event into larger strategic city plans, it was possible to properly complete the restoration works despite the restricted schedule of the mega-event.

The incredible volume of works completed in Genoa through the event cannot be denied. The façade restorations revealed a previously unseen and unknown Genoa, essentially presenting a new city, even to long-time local inhabitants (Fusero 2005). Of the 650 million EUR that Genoa invested in its heritage from 1993 to 2005, nearly a third was allocated for the 2004 event (Gastaldi 2009). To put this figure in perspective, the 200 million EUR spent on restorations and renovations for the 2004 ECoC nearly equals the annual budget of the Ministry of Culture for restoration works for all of Italy in one year (MiBACT 2017). 2004 also represents a key moment of change for Genoa in terms of tourism. Compared to the number of visitors five years prior to the event, there was a $20 \%$ increase during 2004 alone (García and Cox 2013). In 2005, the city received a total of 586,633 overnight visitors, which has since expanded to 801,833 as of 2014 , a $65 \%$ 


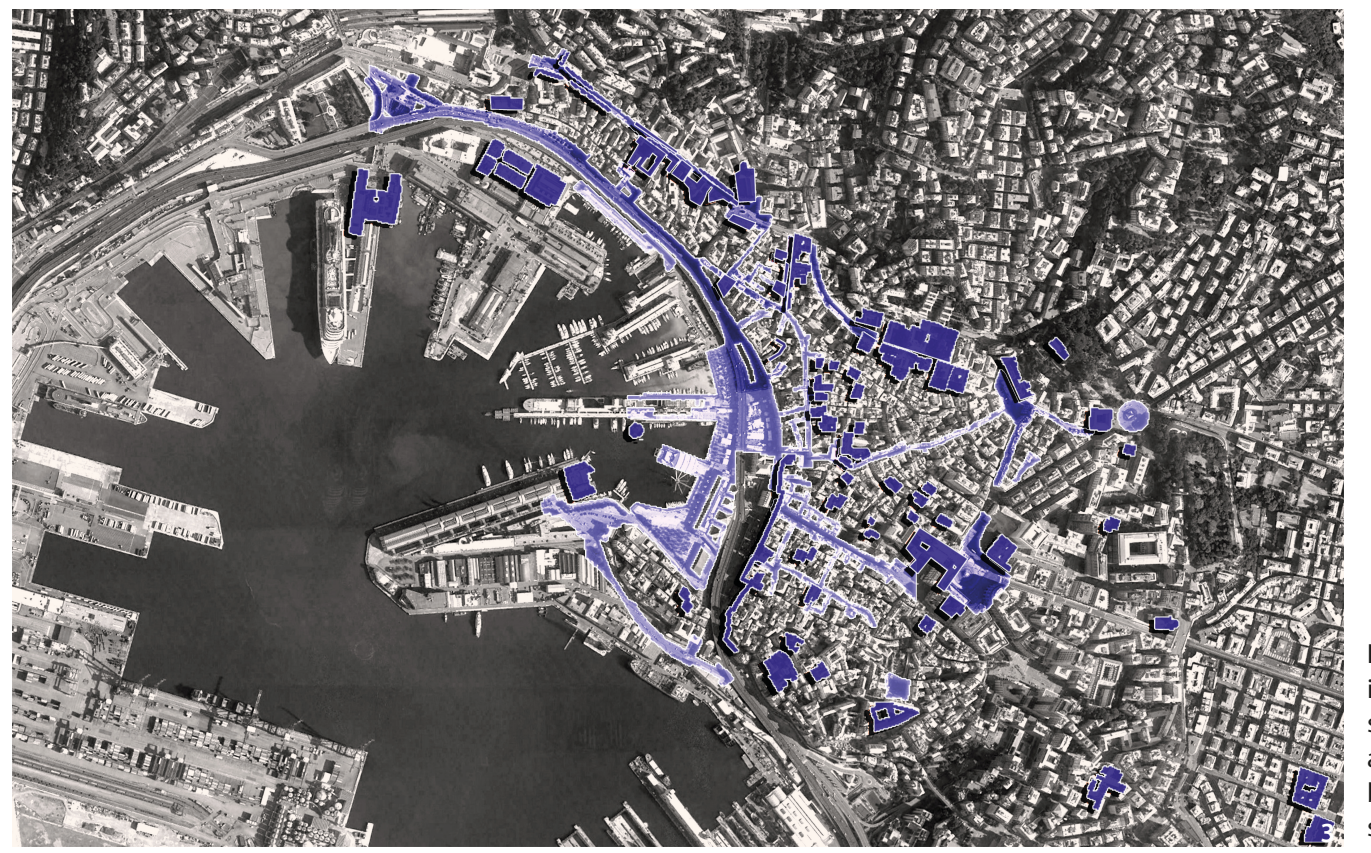

Figure 3 Map of the building projects and public spaces renovated for 2001 and 2004 (Source: drawn by the author, based on Osservatorio Civis). increase (Comune di Genova 2015). The heritage of the city has become a main attractor to draw visitors. Within a national context, the region that Genoa is located in, Liguria, is now the fourth most visited region in Italy. It seems quite clear, based on the available data, that the 2004 $\mathrm{ECoC}$ and the mass restoration works completed through the event have significantly and successfully contributed to establishing Genoa as a cultural destination. The other clearly stated goal for the city was the attainment of UNESCO World Heritage Site status, considered a seal of approval of the transformation of the city and its reputation. In 2006, 'Genoa: Le Strade Nuove and the system of the Palazzi dei Rolli', was recognised with WHS status. A majority of the listed palaces were restored during the works for the events.

However, despite the significant number of improvements, the city yet continues to face a number of social and economic issues with the population continuing to decrease slightly (Comune di Genova 2015). The years following 2004 also witnessed a massive decrease in funding for preservation projects nationally (Bodo and Bodo 2016). The continued regular maintenance of city's newly restored heritage had been cited as a necessary step to prevent ongoing decay and reducing the cost of eventual future interventions (Alcozer 2005; Pittarello 2001; Storti 2005). However, due to the budget reductions, the continued maintenance of heritage was not implemented as hoped. While the mega-event was therefore a great force to organise and motivate actors, it left a void that has been difficult to replace. Though the event successfully engaged and involved a range of actors and institutions at various levels, these networks and the strategic approach that organise them did not continue beyond the event. In this way, the event was able to inspire an innovative governance model utilising existing actors because it was an extraordinary event, but there was no integration of these practices into the post-event return to normal planning practices. Ultimately, this close cooperation of the event management greatly benefited built heritage through the mass physical restoration of the city centre, but these plans were not embedded within broader social or development strategies and policies to ensure their long term success. Therefore, while restored structures remain in good condition, they remain empty and the city has not reversed trends of decreasing population as it had intended. While the perceived success or failure of the event is not responsible for these trends, it reveals the limits of mega-events as the sole strategy to affecting long-term change of such complex economic and social issues in the city.

\section{Liverpool European Capital of Culture 2008: A Distance between Mega-event and Heritage}

Similarly to Genoa, Liverpool also intended to use the ECoC to replicate the success of other cities hosting megaevents in order to reinvent the image of the city (Griffiths 2006). In particular, Liverpool chose to emulate Glasgow (The Liverpool Culture Company Limited 2002), which hosted the 1990 ECoC. However, heritage did not come to play a significant role within the preparations or execution of Liverpool's event. Often cited by academics and 

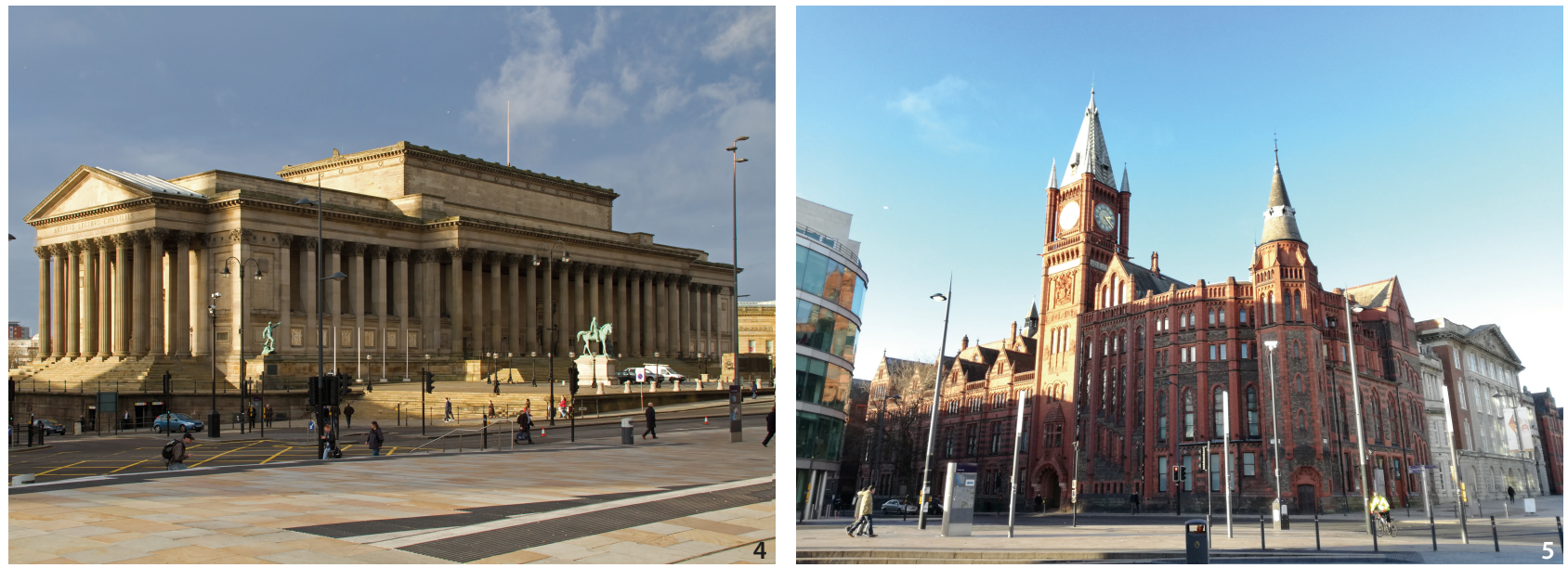

Figure 4 The restored St. George's Hall (Source: Tony Hisgett, Flickr, https://www.flickr.com/photos/hisgett/6727529617/). Figure 5 The Victoria Gallery and Museum (Source: the author).

other bidding cities as one of the most successful ECoCs ever (García, Melville, and Cox 2010), the ECoC has been noted as playing a key role in revitalising the image and economy of the city. Therefore, what are the ramifications for heritage when it is essentially overlooked by a megaevent, essentially the key tool being used to establish the future of the city? Can there still be a benefit for heritage when placed in such a position, or, is there a risk to the long term viability and value of these areas?

Liverpool has a significant amount of built heritage with over 2,700 listed buildings and 36 conservation areas (CA), totalling $9 \%$ of the city's built area (Liverpool City Council 2017). The 'Liverpool-The Maritime Mercantile City' was also recognised as World Heritage by UNESCO in 2004, which comprises much of the waterfront areas and a section of the city centre. Leading up to the 2008 ECoC then, the heritage of Liverpool found itself at an interesting moment. Following decades of decline and abandonment, heritage had come to play a key role in the rebirth of the city starting in the 1980s and culminating in the awarding of WHS (Sykes et al. 2013, Sykes and Ludwig 2015). However, despite all of these efforts, there were yet 440 listed historic buildings at risk in 2009 (Liverpool City Council 2009). Additionally, the entire northern docks area of the WHS was abandoned and inaccessible to the public. However, despite the continued needs of the city's heritage, no restoration projects were directly funded or initiated by the event governing body, the Liverpool Culture Company (LCC), nor did built heritage come to serve as an important factor in the event's program, instead choosing to focus on arts and culture to present a 'new' and more exciting Liverpool. However, while the LCC, directed primarily by the city council, chose not to focus on the city's heritage, a number of private actors and initiatives did initiate several heritage projects for 2008.

Like Genoa, the city also used a series of plans to create an overarching vision for the city, starting with the 20-year Regional Economic Strategy (RES). This strategic plan would provide the basis to other city plans that would come to feature the $2008 \mathrm{ECoC}$ as a key deadline for the city to aim for with the event central to its regeneration (Northwest Regional Development Agency 2000). The ECoC came to serve as the umbrella that unified and showcased various plans culminating in around 2 billion of EU and private funds invested in the city's regeneration and development schemes. These totals dwarfed the eventual 100 million GBP spent solely on the ECoC program, yet all of these plans and projects were eventually coordinated with the event. Likewise, several independent actors also decided to link plans to restore heritage sites with the 2008 program.

The most notable restoration was of St. George's Hall by, a Grade I listed neoclassical building from 1854 that provided the city with law courts along with a town hall and concert room that came to serve as the site for many large public events during 2008 (Figure 4). The project was led by a preservation trust and funded through the Heritage Lottery Fund and the EU Objective One funds. Liverpool University also created The Victoria Gallery and Museum in the original university building that has sat unused for the last several decades (Figure 5). There had been previous attempts to find a new function for the historic building, but the funding and motivation were never sufficient. With the announcement of 2008, the university felt an obligation to contribute and give something back to the city (Clough, personal interview, 2016). Therefore, the 


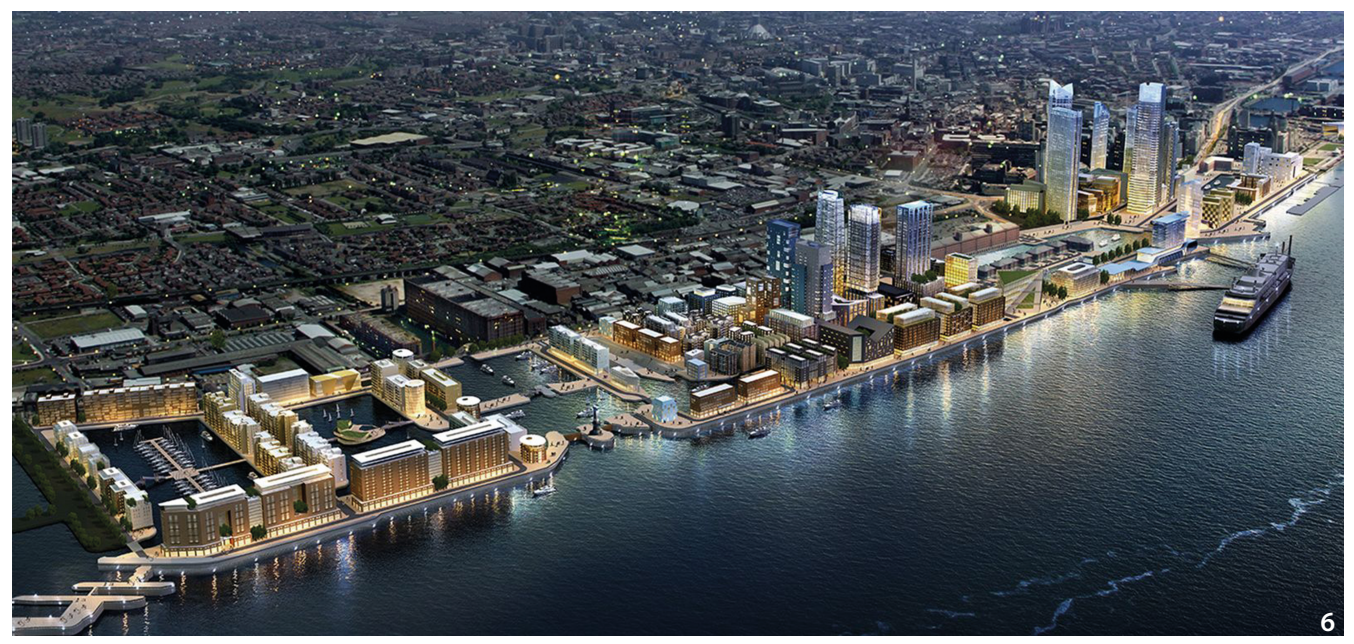

Figure 6 The proposed Liverpool Waters Scheme (Source: Chapman Taylor, http://www.chapmantaylor.com/en/projects/detail/ liverpool-waters/en/).

university agreed to restore the building and establish the gallery and museum, which unified pre-existing collections of the university in one location. Additionally, several historic buildings were restored as hotels in anticipation of the many visitors to the city during the year. Therefore, despite a lack of an official heritage centric program, the event yet served as a catalyst to preserve built heritage.

This indirect link between the 2008 Liverpool ECoC and the city's heritage did not only result in a few projects during the event year, but continued to manifest over the long-term. With a rejuvenated interest in the city, the number of individual listed buildings considered at risk have been drastically reduced in recent years, despite the lack of restoration within the event itself. In 2009, there were 440 listed buildings at risk compared to only 66 in 2016. Many structures have been converted to hotels as well as residences, particularly student housing. Though quantitatively the data is impressive, not all instances of buildings removed from this list would be considered conservation success stories. A series of renovations have led to the destruction and loss of historic buildings in the years since the ECoC such as the demolition of the Dale Street Georgian shops in 2015 and the Futurist Cinema in 2016 amongst others. Additionally, the city's World Heritage site was placed on the List of World Heritage in Danger in 2012 due to the proposed, but not yet implemented, development scheme for Liverpool Waters by The Peel Group.

Liverpool Waters is a 5.5 billion GBP proposed scheme covering 60 ha located in and around Liverpool's northern docks, with portions situated within the WHS and the buffer zone (Figure 6). Despite several design changes, UNESCO has deemed the height of several proposed towers a threat to the Outstanding Universal Vale (OUV) of the site (UNESCO 2012). While the city has enjoyed WHS status since 2004, it has struggled to properly promote this international recognition. In addition to the physical condition of the city's heritage, the last 15 years have also witnessed a clear shift in the official policy towards preservation. While the 2004 Heritage Investment Framework placed the city's heritage as a crucial component for future development, the 2010 update framework does not highlight heritage in the future of the city other than through further cooperation with private developers (Liverpool City Council 2010) and no replacement plan has been produced since its expiration in 2015. There has also been an ongoing reduction in the number of conservation officers devoted to the protection of heritage within the city council as faced with budget cuts.

Liverpool therefore maintains a tenuous relationship with its heritage. The city essentially chose to let the external organisations and the private sector take the lead in re-using and restoring its heritage through regeneration schemes. Over time this approach has resulted in projects that are restored to a high quality, in others it has led to the demolition of sites. The main impact of the event itself can be observed through the secondary effects that have bolstered independent groups to align their actions with the event. This reliance on the intentions of external entities is a potential gamble that does not guarantee heritage protection or promotion. This case also suggests that the positioning of the event does come to impact long term thinking and policy of the city. Heritage has continued to take a backseat to the continued festivalisation and new development of the city. The success of one mega-event may inevitably prescribe their future repetition as Liverpool now hopes to host future large cultural and sporting events. If this strategy comes at the expense of a long-term valuing 


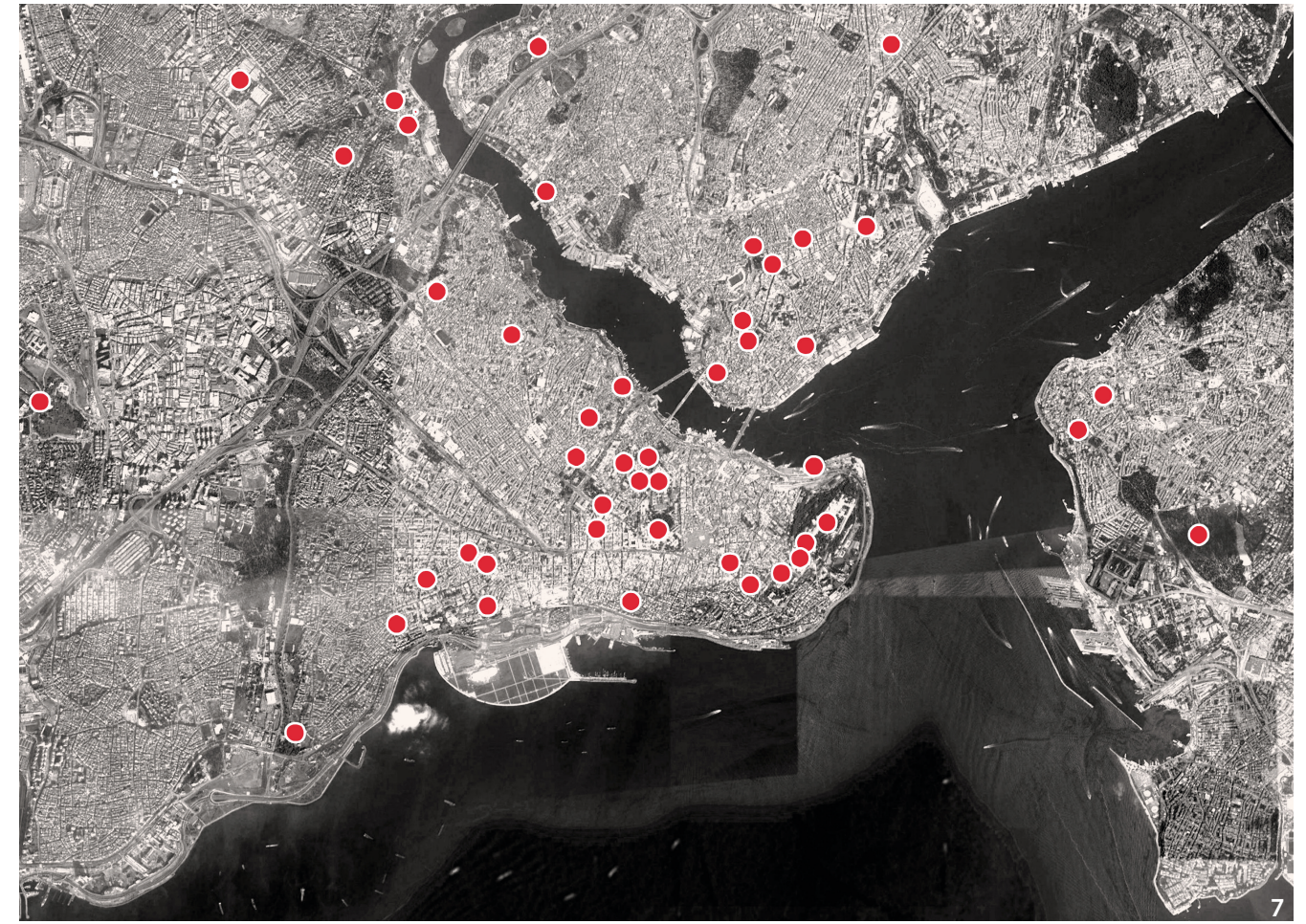

Figure 7 The spread of restoration projects for Istanbul 2010 (Source: the author). of the city's heritage, instead of a coordinated effort, the results could be truly harmful. The current strategy in Liverpool, as stated by the Mayor (Belger 2016), is that buildings are saved when viable. Therefore, regeneration seems to have become the ultimate motto/goal of the city. When heritage can benefit those processes it will be valued and included, but otherwise is viewed as a nuisance or something merely standing in the way of development.

\section{Istanbul European Capital of Culture 2010: Diver- gent Visions and Valuings of Heritage}

Istanbul is a case of extremes. As a city with original settlements dating back 8,000 years and now home to 15 million inhabitants, it tests the limits of a mega-event and its ability to meaningfully impact such a large city. One of the four elements of the theme of the 2010 Istanbul ECoC was the heritage of the city (Istanbul 2010 European Capital of Culture Agency 2012). However, the approach of Istanbul relied far more on an open call for selecting projects with the event unintegrated into a coordinated or strategic set of city plans guiding the works, as seen in both Genoa and Liverpool. The hoped for intention was to increase public participation in Istanbul and Turkey, though in the end these efforts would be quite limited (Öner 2010; Göktürk, Soysal, and Tureli 2010). The framework of institutions responsible for the protection of heritage sites is a fractured and complicated network. In Istanbul, these layers range from the involvement of local municipalities, central ministries, and international organisations. However, the responsibilities and jurisdiction of these actors are often unclear to outside observers as well as to the actors themselves leading to frequent disputes. As noted by Marquart (2014), the management of heritage in Turkey is in a constant state of change and evolution. Though new powers were given to local level authorities in 2004, most of the power remains with central ministries (Bayraktar and Massicard 2012). Under the Ministry of Culture and Tourism (MoCT) exists the General Directorate of Cultural Heritage and Museums and the General Directorate of Religious Foundations that separately manages Ancient/ Byzantine and Islamic/Ottoman heritage sites respectively (Bonini Baraldi and Shoup 2014; Bonini Baraldi, Shoup, and Zan 2013).

Therefore, the newly created 2010 Agency, the body responsible for managing the event, essentially became an additional institution responsible for heritage within this already complicated network, but one that would eventually bring together various actors and complete works that had previously been uncompleted. While the bid for 2010 started life as an entirely bottom-up proposal by several NGOs, the 2010 Agency was ultimately comprised of many central government actors with civil society groups losing influence. As a result, there were varying intentions for the ECoC (Gunay 2010). For some involved, it was primarily seen as an opportunity to advertise the 

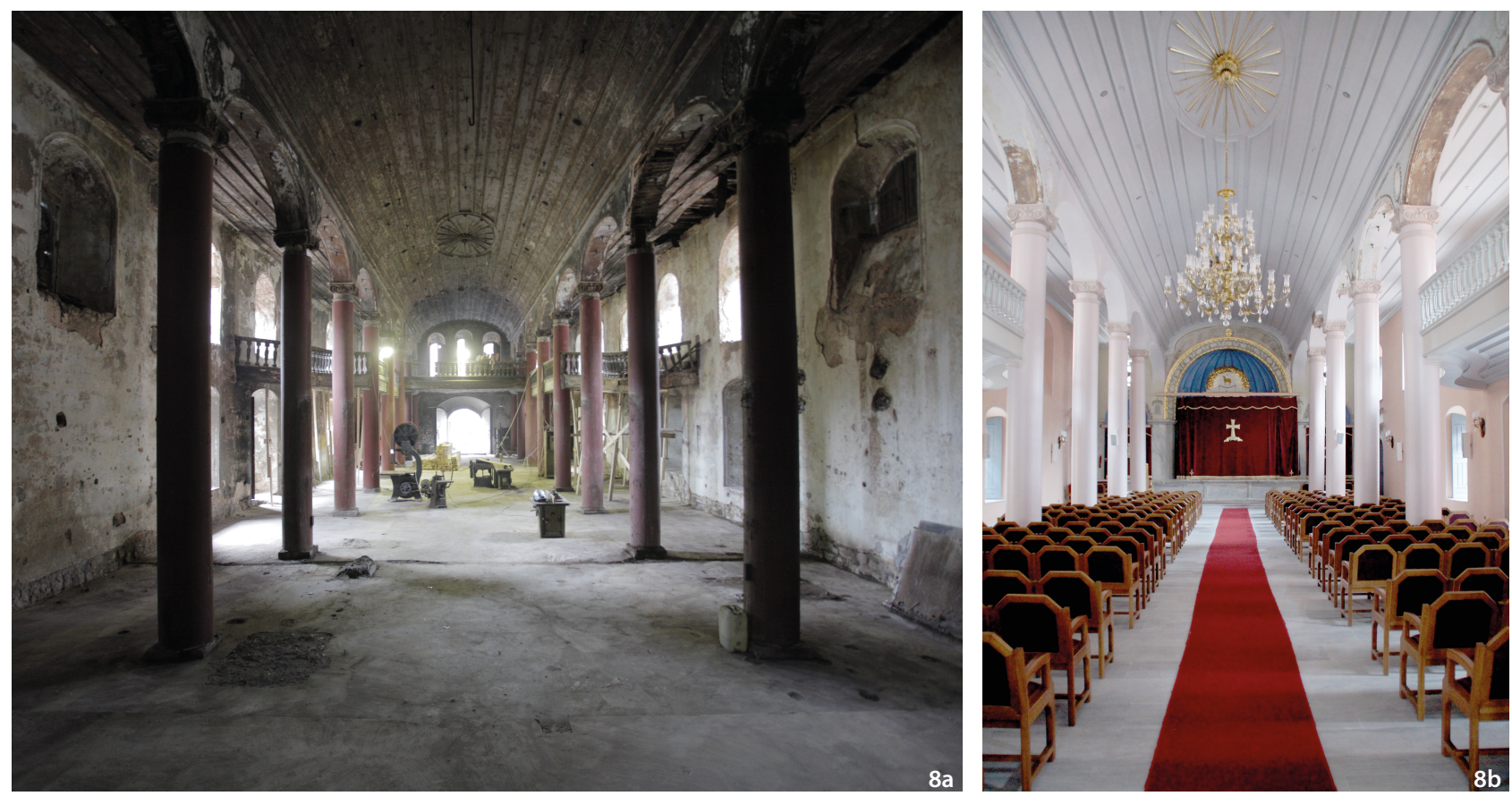

Figure 8a The Vortvots Vordoman Cultural Centre before the restoration in 2010 (Source: Kevork Özkaragöz). Figure $\mathbf{8 b}$ The Vortvots Vordoman Cultural Centre following the restoration in 2010 (Source: the author).

city on a global stage, with its heritage as the main attractor. However, other representatives of the 2010 Agency proposed an alternative vision where arts, culture and heritage were localised to make them more accessible to local citizens in areas where they normally do not exist. In the end, both of these intentions are represented in the event in some ways. The event's emphasis on built heritage is clearly seen in Law 5706 (Republic of Turkey 2007) which encouraged urban regeneration projects with a specific emphasis on built heritage, even proposing specific projects ${ }^{1}$. However, the initial emphasis for focusing the $\mathrm{ECoC}$ on heritage can be found even earlier, when mission reports by UNESCO suggest utilising the 2010 ECoC as a tool to restore threatened sites, recognising the additional funding and urgency of the event as potential heritage resources ${ }^{2}$ (UNESCO 2006, 2008).

Istanbul contains a wide range of built heritage crossing many eras and cultures. The most noted heritage sites in Istanbul are included in the Historic Areas of Istanbul, the four WHS properties located on the Historic Peninsula: the Archaeological Park, which includes Topkapi Palace, Hagia Sophia and the Sultanahmet Mosque (Blue Mosque); the Suleymaniye quarter and Mosque complex; the Zeyrek area surrounding the Zeyrek Mosque (former Pantocrator church) and the ancient Theodosian land walls (Figure 7). The ECoC was an opportunity to both implement restoration works on religious, civil, military and even industrial sites spanning the Republican,
Ottoman and Byzantine eras and ranged from some of the city's grandest and most well-known built heritage (including Hagia Sofia, Sultanahmet Square and Topkapi Palace) to rather small and virtually unknown sites along with several urban pedestrianisation schemes. In total, the event was responsible for over 50 separate restoration projects (Istanbul 2010 European Capital of Culture Agency 2012), several of which were in a severe state of degradation prior to the event, such as the Vortvots Vordomon Church, which had been abandoned for over a century (Figure 8a, Figure 8b). This important Armenian heritage property likely would have otherwise remained left to decay as prior attempts to raise funding for the project over the previous decade had been unsuccessful. Notably, this project was the first ever Armenian cultural property to be funded by the Turkish Government, representing a significant step in the recognition of the country's diverse past and heritage. The Historic Wooden Home Repair Program implemented in the Zeyrek and Süleymaniye areas was another important project that brought together several existing institutions to not only restore some of the iconic wooden homes of Istanbul, but also to develop training programs to provide the skill sets and knowledge of traditional construction methods (Istanbul 2010 European Capital of Culture Agency 2011).

In addition to the physical works completed, two important heritage plans were produced as part of the 2010 event: The Historic Peninsula Site Management Plan 


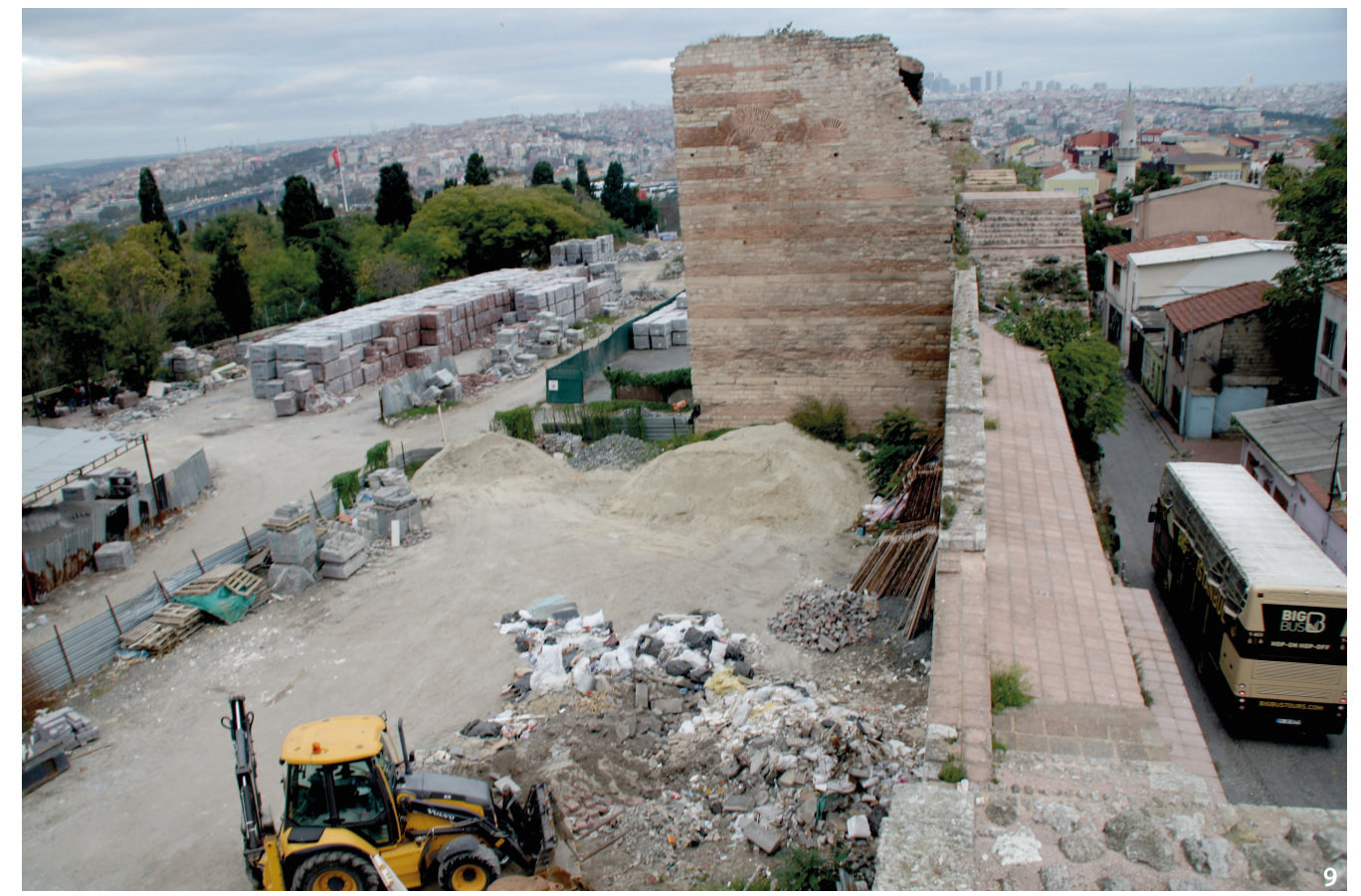

Figure 9 Condition of the Fatih Davutpaşa Medresesi as of January, 2016 (Source: the author).
(SMP) (ISMD 2011) and the Sur-i Sultani Strategic Vision (Metaphor 2009). While the $2010 \mathrm{ECoC}$ solely funded and did not develop these plans, they were both important attempts to secure the city's heritage for the future and generate a long-term vision that had been previously lacking (Istanbul 2010 European Capital of Culture Agency 2012). Unfortunately, neither plan has been implemented to the degree hoped for. The SMP seems to have lost the ability to cast a forward thinking vision for the future that could be effectively implemented (Bonini Baraldi, Shoup, and Zan 2013). However, with the completion of both of these strategic documents, UNESCO decided to remove the Istanbul WHS from consideration for the warning list. Additionally, the 2010 Agency was also able to bring together heritage actors from throughout the city that had previously not worked together. New networks were created between local actors with weekly meetings including academics, practitioners and elected officials to engage in conversations about the pressing issues facing the city and its urban heritage. While the 2010 Agency was not exclusively a heritage body, it was in many ways able to 'fill the gaps' within the complex heritage network for a period of time. The final report by Ernst-Young (2011) notes that 49\% (137 million EUR) of the total budget of the ECoC was devoted to the city's heritage. While a significant investment for the city's heritage, Karaca (2013) argues that a mega-event should not have been necessary to ensure the financing of these restoration projects in the first place, but rather already regularly maintained and promoted.
Overall, the 2010 ECoC contributed greatly to the city in terms of much needed physical regeneration, management structures and promoting a culture of preservation of built heritage. However, while the event was used to impact a broad range of heritage, the hard deadline of the event and significant investments may not have been enough to create a lasting impact. Of the 52 restoration projects, 14 were not finished by 2010 and an additional 14 were either never completed or are still undergoing restoration works. Ultimately, this meant that over 28 projects, or more than $50 \%$ of the proposed projects were not completed in time for the celebration of 2010 itself. Looking at the budget for these projects, these total 28 projects represent $72 \%$ of the total funding of urban heritage projects for the ECoC. The 14 remaining unfinished projects represents $16 \%$ of the total budget. In this instance, the hard deadline of the event was in some ways a negative aspect that resulted in unfinished projects which remain incomplete to this day and show either no or very slow signs of continuing works since the dissolution of the 2010 Agency (Figure 9). Additionally, the final selection of projects was quite ad hoc due to the lack of an overall plan and therefore project proposals with already prepared plans were selected, in most cases those being projects from local municipalities or central ministries. Therefore, public involvement in the event's open call for projects was ultimately quite limited and never developed to the degree originally intended by certain actors. 
The works completed as part of the 2010 ECoC represent an important turning point for Istanbul and the protection of its heritage, as recognised by UNESCO rescinding its possible inclusion on the Heritage in Danger List. In this case, the ECoC was responding to an emergency scenario in terms of the city's heritage. Without a doubt, many of the heritage assets of the city would yet be decaying and abandoned if it were not for the event. In this sense, the event has been invaluable in ensuring the continuation of these heritage sites for future generations. The efforts made for inclusivity and a participatory approach should be applauded, particularly in a context like Turkey where such practices are not common. However, this structure, which lacked a single cohesive plan for the event and was divorced from other strategies for the city resulted in reduced efficiency and spread out projects with no clear cohesion between them. While the event funded several training workshops in conservation methods, a 2014 report calls into question the state of preservation of Istanbul's monuments and requests UNESCO to reconsider the properties for the World Heritage in Danger list. Specifically, the report sites ongoing practices at construction sites that have directly damaged the Theodosian Land Walls, one of the four WHS (Çorakbaş, Aksoy, and Ricci 2014). Urban regeneration schemes have also continued to be implemented in historic areas, leading to their continued loss (Marquart 2014; Yetiskul, Kayasü, and Ozdemir 2016; Yildirim 2015). Therefore, while the event was an effective engine to address short term and immediate problems, it was not as successful in addressing many of the embedded systematic shortcomings in the existing complex governance structure of the city's heritage. Also, while the investment was significant, it was perhaps not adequate to meet the need of a city like Istanbul with such a vast heritage offering. Ultimately, in a city as large as Istanbul, it would be difficult for an event of any magnitude to dramatically impact in a cohesive and consistent way.

\section{Conclusions: Consequences of the Inherent and Secondary Effects of Mega- events on Urban Heritage}

The three cases presented in this paper clearly show that first, mega-events can in fact intervene and affect urban heritage in significant ways, but secondly, that these processes happen not only through specifically planned actions, but also the unplanned secondary effects of megaevents. Most obviously, they can serve as opportunities of significant funding to restore and renovate built heritage, an occasion to unify actors within an accelerated timeline as well as introduce a new heritage-centric focus to the city where one may not have previously existed. Genoa successfully used the event to first complete a massive restoration of the urban core and subsequently establish itself as a new cultural heritage destination. While the city may yet have other issues it must continue to address, its heritage has been recognised by UNESCO and its tourism continues to grow. The event can serve as a mechanism to protect heritage and address emergency situations of physical decay that otherwise might be lost, particularly in cities that may not be known as a heritage destination. However, cities must be careful to properly manage and integrate such efforts into comprehensive and strategic city plans. While an event may be successful to initiate short term goals, a city cannot rely solely on the event, it must plan long-term to maintain and protect its heritage. Therefore, while increased funding and expedited delivery can benefit heritage, their focus and implementation are crucial.

While Istanbul also used the event to focus on and restore its heritage, these efforts were disconnected from an overall city plan or strategy, resulting in a diffused incoherent outcome. Having the event embedded within larger plans also provides greater assurance that desired projects will be completed. Both a potential benefit and drawback of the mega-event is its restricted and steadfast deadline. While this aspect may motivate actors to work together and accomplish tasks on time, it can also result in rushed works that harm instead of protect heritage. Even if the physical restoration is properly carried out, but the long-term care, maintenance or use is not planned for, the site can quickly return to being at risk of continuing degradation. In Istanbul, many of the projects started, but unfinished for 2010 have remained in precarious situations as there were no long-term provisions for their completion following the loss of the structure and funding of the 2010 Agency.

Beyond the intended direct effects, it is also important to note the secondary effects of mega-events and their potential influence on heritage. Liverpool well illustrates the potential for positive secondary effects for heritage from an event as it served as an umbrella for separate institutions to privately fund restoration projects that would coalesce with the yearlong celebrations. On the other hand, over the long-term, the lack of focus on heritage may have contributed to city officials valuing its heritage solely for its development potential. Beyond physical impacts, the governance structure of mega-events can provide an opportunity to bring together heritage actors from local to national levels. Though unrealised in Istanbul, the intentions by some actors to include public participation in 
decision making highlights the possibility for future cities to incorporate local citizens in these processes.

In conclusion, the potential very much exists for mega-events to serve as an impetus for innovative heritage renewal and promotion in vastly varying contexts, but requires the involvement of heritage actors in these processes and integration of the event into long-term plans and goals. As noted earlier in this article, mega-events may soon be more commonly found within city centres and not just as enclaves located on peripheries. Therefore, they will increasingly become a potential tool for conservationists and planners to use for the benefit of urban heritage, not only in the European, but global context, which up till now has not been broadly considered or discussed. Otherwise, the potential remains that both the inherent and secondary qualities of mega-events pose significant risks to the historic built environment of future host cities if not included as part of planning and decision making processes.

\section{Notes}

1. Law 5706 called for the restoration of the Rami Army barracks, the Sisli Cultural Centre and the AKM centre; however, the works on the AKM centre were halted and remains unfinished, while no works were even begun for the Rami Army barracks or Sisli Cultural Centre.

2. In 2003, UNESCO announced that Istanbul's four WHS would be considered for inclusion on the World Heritage in Danger List. Of particular concern was the lack of a proper site management plan for the four WHS areas as well as the whole of the historic peninsula.

\section{References}

Alcozer, Federica. 2005. "Il Processo Di Trasformazione Di Una Città Europea." Urbanistica 57 (126): 78-80.

Graham, Brian, Gregory Ashworth, and John Tunbridge. 2007. Pluralising Pasts: Heritage, Identity and Place in Multicultural Societies. London: Pluto Press.

Basso, Matteo. 2017. Grandi Eventi E Politiche Urbane: Governare "routine Eccezionali" un Confronto Internazionale. Milan: Guerini e Associati.

Bayraktar, S. Ulas, and Elise Massicard. 2012. "Decentralisation in Turkey." Agence Française de Développement, Focales: 112.

Belger, Tom. 2016. "Demolition of Historic Futurist Cinema in Liverpool Begins: Hours after Campaigners' Appeal Dismissed." Liverpool Echo, August 2. http:// www.liverpoolecho.co.uk/news/liverpool-news/demolition-historic-futurist-cinema-liverpool-11696348.

Bodo, Carla, and Simona Bodo. 2016. "Country Profile: Italy." Compendium: Cultural Policies and Trends in Europe.

Bonfantini, G. Bertrando. 2015. "Historic Urbanscapes For Tomorrow, Two Italian Cases: Genoa And Bologna." European Spatial Research and Policy 22 (2): 57-71.

Bonini Baraldi, Sara, and Daniel David Shoup. 2014. "Heritage Management at the Local Level: Rhetoric and Results in the Case of Gaziantep, Turkey." International Journal of Cultural Policy 20 (5): 588-612.

Bonini Baraldi, Sara, Daniel Shoup, and Luca Zan. 2013. "Understanding Cultural Heritage in Turkey: Institutional Context and Organisational Issues.” International Journal of Heritage Studies 19 (7): 728-748.

Carbonara, Giovanni. 2001. "Un Bilancio Positivo.” Arkos, Speciale G8, 2 (1): 6-10.

Comune di Genova. 1999. “1 Sessione 'Genova: Città Della Cultura E Del Turismo.” In Genova: Le Vie Del Mediterraneo All'europa.

Comune di Genova. 2000. "Il Piano Operativo per Il Centro Storico."

Comune di Genova. 2015. "Annuario Statistico, Edizione 2015." Genova. http://statistica.comune.genova.it/pubblicazioni/download/annuario/ANNUARIO\%202015/ ANNUARIO\%202015.pdf

Çorakbaş, Figen Kıvılcım, Asu Aksoy, and Alessandra Ricci. 2014. "A Report of Concern on the Conservation Issues of the Istanbul Land Walls World Heritage Site: With a Special Focus on the Historic Yedikule Vegetable Gardens (Yedikule Bostanları).”

Ernst \& Young. 2011. "Istanbul 2010: European Capital of Culture Impact Assessment Report."

Fusero, Paolo. 2005. Genoa the Periphery and Historical Centres: Behind the Scenes of the 2004 European Capital of Culture. Pescara: SALA editori.

Gabrielli, Bruno. 2005. "Genova, Un Piano Strategico Di Natura Operativa Ei Suoi Esiti." Urbanistica 126: 57-63.

García, Beatriz. 2005. "Deconstructing the City of Culture: The Long-Term Cultural Legacies of Glasgow 1990." Urban Studies 42 (5): 841-868.

García, Beatriz, and Tasmin Cox. 2013. "European Capitals of Culture: Success Strategies and Long-Term Effects." Luxembourg: European Parliament Committee on Culture and Education.

García, Beatriz, Ruth Melville, and Tamsin Cox. 2010. “Creating an Impact: Liverpool's Experience as 
European Capital of Culture." Final report of the Impacts 08 programme.

Garden, Mary-Catherine E. 2006. “The Heritagescape: Looking at Landscapes of the Past." International Journal of Heritage Studies 12 (5): 394-411.

Gastaldi, Francesco. 2009. "Genova, Dalle Colombiane a Capitale Europea Della Cultura. Grandi Eventi E Processi Di Rigenerazione Urbana." Territorio, 110-114.

Gastaldi, Francesco. 2016. "Genoa, a Success Story!” In Waterfronts Revisited: European Ports in a Historic and Global Perspective, edited by Heleni Porfyriou and Marichela Sepe, 123-133. London: Routledge.

Göktürk, Deniz, Levent Soysal, and Ipek Tureli, eds. 2010. Orienting Istanbul: Cultural Capital of Europe? London: Routledge.

Gold, John R, and Margaret M. Gold. 2016. Olympic Cities: City Agendas, Planning, and the World's Games, 1896-2020. London: Routledge.

Gómez, María V. 1998. "Reflective Images: The Case of Urban Regeneration in Glasgow and Bilbao.” International Journal of Urban and Regional Research 22 (1): 106-121.

Graham, Brian. 2002. "Heritage as Knowledge: Capital or Culture?” Urban Studies 39 (5-6): 1003-1017.

Griffiths, Ron. 2006. “City/Culture Discourses: Evidence from the Competition to Select the European Capital of Culture 2008." European Planning Studies 14 (4): 415-430.

Gunay, Zeynep. 2010. “Conservation versus Regeneration?: Case of European Capital of Culture 2010 Istanbul." European Planning Studies 18 (8): 1173-1186.

Harrison, Rodney. 2013. Heritage: Critical Approaches. London: Routledge.

Harvey, David C. 2008. “The History of Heritage." In The Ashgate Research Companion to Heritage and Identity, edited by Brian Graham and Peter Howard, 19-36. Farnham: Ashgate.

Horne, John, and Wolfram Manzenreiter. 2006. "An Introduction to the Sociology of Sports Mega-events." The Sociological Review 54 (s2): 1-24.

International Olympic Committee. 2014. Olympic Agenda 2020: 20+ 20 Recommendations.

Istanbul Site Management Directorate (ISMD). 2011. "Istanbul Historic Peninsula Site Management Plan." BIMTAŞ A. Ş.

Istanbul 2010 European Capital of Culture Agency. 2011. “Kentsel Projeler: Restorasyon.” Istanbul.

Istanbul 2010 European Capital of Culture Agency. 2012. “2010 Program: 365 Days 549 Projects.” Istanbul.
Karaca, Banu. 2013. "Europeanization from the Margins? Istanbul's Cultural Capital Initiative and the Formation of European Cultural Policies." In The Cultural Politics of Europe: European Capitals of Culture and European Union since 1980s, edited by Kiran Klaus Patel, 157176. London; New York: Routledge.

Liverpool City Council. 2009. "Liverpool Buildings at Risk Register - July 2009.”

Liverpool City Council. 2010. "Recall the Past to Inform the Future: A Heritage Investment Framework for the City of Liverpool."

Liverpool City Council. 2017. “Conservation Areas.” Accessed February 16 2017. https://liverpool.gov.uk/ planning-and-building-control/conservation-areas/.

Lowenthal, David. 1985. The Past Is a Foreign Country. Cambridge University Press.

Marquart, Vivienne. 2014. "Insurmountable Tension? On the Relation of World Heritage and Rapid Urban Transformation in Istanbul." European Journal of Turkish Studies. Social Sciences on Contemporary Turkey 2014 (19): 1-25. https://ejts.revues.org/5044

Mason, Randall, and Erica Avrami. 2002. "Heritage Values and Challenges of Conservation Planning." In Management Planning for Archaeological Sites, edited by Jeanne Marie Teutonico and Gaetano Palumbo, 13-26. Los Angeles: Getty Conservation Institute.

McGillivray, David, and Gayle McPherson. 2012. "Mega Events: Neoliberalized Vehicle or Opportunity for Strategic Global Leadership." Journal of Leadership, Accountability and Ethics 9 (5): 80-91.

Metaphor. 2009. “Sur-I Sultani Strategic Vision.” London. Accessed April 10 2015. http://www.metaphor.eu/projects/sur-i-sultani-cultural-quarter/

Ministry of Culture (MiBACT). 2017. “Ministero." http:// www.beniculturali.it/mibac/export/MiBAC/sito-MiBAC/MenuPrincipale/Ministero/index.html

Mooney, Gerry. 2004. "Cultural Policy as Urban Transformation? Critical Reflections on Glasgow, European City of Culture 1990.” Local Economy 19 (4): 327-340.

Németh, Ágnes. 2015. "European Capitals of CultureDigging Deeper into the Governance of the MegaEvent." Territory, Politics, Governance 4 (1): 52-74.

Northwest Regional Development Agency. 2000. "Regional Economic Strategy."

Öner, Oğuz. 2010. "Istanbul 2010 European Capital of Culture: Towards a Participatory Culture?” In Orienting Istanbul: Cultural Capital of Europe, edited by Deniz Göktürk, Levent Soysal and Ipek Tureli, 267278. London: Routeledge. 
Palmer/RAE Associates. 2004. "European Cities and Capitals of Culture. Part I." Brussels: European Commission.

Pittarello, Liliana. 2001. "Molti Lavori per Un Complessivo Intervento Di Restauro Urbano." Arkos, Speciale G8 2 (1): 11-17.

Ponzini, Davide, and Zachary Jones. 2015. "Meanings, Urban Products and Forms of 'European Cities' in the European Capital of Culture Program.” Urbanistica 155: 70-78.

Republic of Turkey. 2007. "Law 5706: Law on the Istanbul 2010 Capital of Culture.” Accessed May 30 2017. http:// www.mevzuat.gov.tr/MevzuatMetin/1.5.5706.pdf

Robertson, Douglas. 1996. "Housing, Planning and the Economy." Planning Department Spring Seminar Series, Glasgow City Council, March.

Roche, Maurice. 1994. "Mega-events and Urban Policy." Annals of Tourism Research 21 (1): 1-19.

Roche, Maurice. 2002. Megaevents and Modernity: Olympics and Expos in the Growth of Global Culture. London: Routledge.

Short, John R. 2008. "Globalization, Cities and the Summer Olympics.” City 12 (3): 321-340.

Storti, Maristella. 2005. "Genova Capitale Europea Della Cultura 2004." Ri-Vista 3 (1): 86-89.

Sykes, Olivier, Jonathan Brown, Matthew Cocks, David Shaw, and Chris Couch. 2013. "A City Profile of Liverpool." Cities 35: 299-318.

Sykes, Olivier, and Carol Ludwig. 2015. "Defining and Managing the Historic Urban Landscape: Reflections on the English Experience and Some Stories From Liverpool." European Spatial Research and Policy 22 (2): 9-35.

The Liverpool Culture Company Limited. 2002. "Liverpool 2008: European Capital of Culture Bid."

UNESCO. 2006. "Joint ICOMOS/UNESCO (WHC) Expert Mission Report: Historic Areas of Istanbul (Turkey) (C 356)." Vilnius.

UNESCO. 2008. "Mission Report: Historic Areas of Istanbul (Turkey) (356)." Quebec.

UNESCO. 2012. "Decisions Adopted By The World Heritage Committee at Its 36th Session." St. Petersburg.

UNESCO. 2017. “Tangible Cultural Heritage.” Accessed May 30 2017. http://www.unesco.org/new/en/cairo/ culture/tangible-cultural-heritage/

Yetiskul, Emine, Serap Kayasü, and Suna Yaşar Ozdemir. 2016. "Local Responses to Urban Redevelopment Projects: The Case of Beyoğlu, Istanbul." Habitat International 51: 159-67.
Yildirim, Ayşe Ege. 2015. “The Changing Role of Urban Heritage: Governance and Stakeholders' Perceptions in Turkey and The United Arab Emirates." Middle East Technical University, Journal of the Faculty of Architecture 1: 121.

Young, Kevin, and Kevin Wamsley, eds. 2005. Global Olympics: Historical and Sociological Studies of the Modern Games. Bingley: Emerald Group Publishing Limited.

Zimbalist, Andrew. 2015. Circus Maximus: The Economic Gamble behind Hosting the Olympics and the World Cup. Washington: Brookings Institution Press. 